Novita Olivia, Farid Rusdi: Efektivitas Penggunaan Media Sosial @ Kemendagri Terhadap Pemenuhan Kebutuhan Informasi Publik (Survei Pada Pengikut Akun Instagram @ Kemendagri)

\title{
Efektivitas Penggunaan Media Sosial @Kemendagri Terhadap Pemenuhan Kebutuhan Informasi Publik (Survei Pada Pengikut Akun Instagram @Kemendagri)
}

\author{
Novita Olivia ${ }^{1}$, Farid Rusdi ${ }^{2}$ \\ ${ }^{1}$ Fakultas Ilmu Komunikasi, Universitas Tarumanagara, Jln Letjen S. Parman No. 1, Jakarta \\ Email: novita.915180281@stu.untar.ac.id \\ ${ }^{2}$ Fakultas Ilmu Komunikasi, Universitas Tarumanagara, Jln Letjen S. Parman No. 1, Jakarta \\ Email:farid@fikom.untar.ac.id
}

Masuk tanggal : 15-12-2021, revisi tanggal : 06-01-2022, diterima untuk diterbitkan tanggal : 16-01-2022

\begin{abstract}
In this digital era, it is easier for people to find information. The development of the digital era is currently happening very quickly in society with the internet. The emergence of the internet is then the existence of social media such as Instagram. Currently, many institutions have created special Instagram accounts to provide information to the public. One of the Ministry of Home Affairs government agencies has an Instagram social media account, namely@Kemendagri to upload information about the Ministry of Home Affairs. This study discusses the effectiveness of the use of @kemendagri social media in meeting the needs of public information. The theory in this study is satisfaction and use which explains that individuals can choose media to fulfill their needs through these media. This study uses quantitative research methods, survey methods and data collection techniques in this study through distributing questionnaires to 100 samples determined through probability sampling and simple random sampling. The results obtained by the correlation coefficient indicate a strong relationship between the variable $X$ and variable $Y$. From the results of the coefficient of determination the contribution of variable $X$ to variable $Y$ is $54.2 \%$. The results of hypothesis testing in this study showed that the independent variable had a positive and significant effect on the dependent variable. The conclusion that can be given is that the use of social media Instagram @ kemendagri is effective in meeting the needs of public information through theory testing.
\end{abstract}

Keywords: @kemendagri, instagram, public information needs, social media

\begin{abstract}
Abstrak
Di era digital seperti sekarang ini, masyarakat semakin mudah untuk mencari informasi. Perkembangan era digital saat ini terjadi sangat cepat di masyarakat dengan adanya internet. Munculnya internet ini kemudian adanya media sosial seperti Instagram. Saat ini banyak institusi yang membuat akun Instagram khusus untuk memberikan informasi kepada masyarakat. Salah satu instansi pemerintah Kementerian Dalam Negeri memiliki akun media sosial Instagram yaitu@Kemendagri untuk mengunggah informasi seputar Kementerian Dalam Negeri. Penelitian ini membahas tentang efektivitas penggunaan media sosial @kemendagri dalam memenuhi kebutuhan informasi publik. Teori dalam penelitian ini adalah kepuasaan dan penggunaan yang menjelaskan bahwa individu dapat memilih media untuk pemenuhan kebutuhannya melalui media tersebut. Penelitian ini menggunakan metode penelitian kuantitatif, metode survei dan teknik pengumpulan data dalam penelitian ini melalui penyebaran kuesioner kepada 100 sampel yang ditentukan melalui probability sampling dan simple random sampling. Hasil yang diperoleh koefisien korelasi menunjukkan adanya hubungan yang kuat antara variabel $\mathrm{X}$ dan variabel $\mathrm{Y}$. Dari hasil koefisien determinasi kontribusi variabel $\mathrm{X}$ terhadap variabel $\mathrm{Y}$ sebesar $54,2 \%$. Hasil uji hipotesis dalam penelitian
\end{abstract}


ini diperoleh hasil bahwa variabel bebas berpengaruh positif dan signifikan terhadap variabel terikat. Kesimpulan yang dapat diberikan adalah penggunaan media sosial Instagram @kemendagri Efektif terhadap pemenuhan kebutuhan informasi publik melalui pengujian teori.

Kata Kunci: @kemendagri, instagram, kebutuhan informasi publik, media sosial

\section{Pendahuluan}

Komunikasi adalah suatu proses membagikan informasi atau pesan kepada manusia satu ke manusia yang lain untuk saling berhubungan dan berinteraksi. Komunikasi merupakan bentuk yang penting dalam sebuah organisasi untuk berhubungan dengan masyarakat melalui membagikan informasi terhadap masyarakat. Komunikasi saat ini tidak hanya dilakukan melalui tatap muka namun dapat melalui media massa pada era digital saat ini.

Era digital adalah kondisi dimana masyarakat telah dimudahkan dalam kehidupan dengan adanya teknologi. Perkembangan era digital saat ini terjadi sangat cepat pada masyarakat dengan adanya internet. Adanya Internet memudahkan setiap informasi dapat tersampaikan dengan cepat dan dapat dilihat dimanapun dan kapanpun yang dapat diakses melalui telpon genggam, laptop, komputer. Munculnya internet, maka adanya media sosial seperti Instagram merupakan aplikasi yang sering diakses oleh para pengguna di Indonesia adalah Instagram.

Instagram sebagai aplikasi untuk mengunggah foto dan video. Saat ini banyak institusi-institusi mempunyai akun instagram yang dibuat khusus untuk memberikan informasi terhadap khlayak. Salah satunya Institusi pemerintahan Kementerian Dalam Negeri RI ini adalah pemerintah dalam Indonesia yang membidang seluruh urusan dalam negeri dan berhubungan langsung terhadap masyarakat jadi instagram ini memudahkan untuk masyarakat dari luar daerah maupun dari mancanegara untuk mencari informasi tentang kemendagri dan berita-berita menyangkut urusan dalam negeri jadi masyarakat dimudahkan dengan kebutuhan informasi yang akan didapatkan.

Akun instagram@kemendagri harus memiliki efektivitas yang tinggi untuk memenuhi kebutuhan informasi terhadap khalayak. Pengertian efektivitas menurut (Maunley, 2016), ini sendiri merupakan syarat untuk memilih tujuan yang ingin dicapai dengan cara atau peralatan yang digunakan untuk memperoleh hasil yang memuaskan. Dalam hal ini cara yang digunakan Kementerian Dalam Negeri salah satunya yaitu instagram dalam memberikan informasi untuk memenuhi kebutuhan informasi terhadap publik yang merupakan pengikut akun instagramnya.

Tujuan dalam penelitian ini ingin mengetahui seberapa besar tingkat penggunaan media sosial akun instagram @kemendagri efektivitas terhadap pemenuhan kebutuhan informasi publik. Lalu rumusan masalah dalam penelitian ini seberapa efektif penggunaan media sosial akun instagram @kemendagri terhadap pemenuhan kebutuhan informasi publik.

1. Uses and Gratification ( Teori Kepuasaan dan Penggunaan) menurut (Ardianto, 2011) kepuasaan dan penggunaan adalah perilaku aktif individu memilih media tersebut untuk pemenuhan kebutuhannya khalayak melalui penggunaan media tersebut.

2. Media sosial (Utari, 2011) media elektronik untuk masyarakat menyampaikan dan memperoleh informasi, membuat unggahan yang ingin dibagikan ke para pengguna lain, serta memberikan masukan dan umpan balik atas konten tersebut. 
Novita Olivia, Farid Rusdi: Efektivitas Penggunaan Media Sosial @ Kemendagri Terhadap Pemenuhan Kebutuhan Informasi Publik (Survei Pada Pengikut Akun Instagram @ Kemendagri)

Berbagai macam media sosial dapat dipilih oleh masyarakat untuk memenuhi kebutuhannya. Melalui 4C penggunaan media sosial menurut (Solis, 2011;63) untuk memenuhi kebutuhan informasinya yaitu Context, Communication, Collaboration, Connection

3. Kebutuhan Informasi

Terjadi karena keadaan yang muncul yaitu ketidakseimbangan antara pengatuhan yang dimiliki kurang dengan yang diperlukan, sehingga menggerakan individu untuk memperoleh berita lebih untuk pemenuhan kebutuhannya (Perdana , 2012). Terdapat empat pendeketan kebutuhan informasi Current need approach, Everday need approach, Exhaustic need approach, Catching-up need approach.

4. Efektivitas

Efektivitas (Maunley, 2016), ini sendiri merupakan syarat untuk memilih tujuan yang ingin dicapai dengan cara atau peralatan yang digunakan untuk memperoleh hasil yang memuaskan.

\section{Metode Penelitian}

Metode yang digunakan kuantitatif yang datanya berupa angka yang diolah melalui teknik statistik. Peneliti mengggunakan survei atau kuosioner. Melalui kuosioner yang disebarkan peneliti data memperoleh data dari populasi tersebut untuk memberikan jawaban bagi penelitian ini.

Peneliti ini menggunakan pengikut Instagram @kemendagri sebagai populasi, yang jumlahnya dapat bertambah maupun berkurang dalam setiap harinya dan jumlah pengikut per tanggal 5 September 2021 sebanyak 251.000 pengikut. Teknik digunakan dalam penelitian ini probability sampling yaitu semua populasi bisa dijadikan sampel dan Teknik yang digunakan untuk pengambilan sampel simple random sampling jadi penarikan sampel tidak melihat kriteria responden jadi peneliti bebas memilih respondennya, maka peneliti menggunakan rumus Yamane dan didapatkan 100 untuk dijadikan sampel dan dibagikan kuosioner.

\section{Hasil Penemuan dan Diskusi}

Tabel 1. Uji validitas Penggunaan Akun instagram @ kemendagri

\begin{tabular}{llll}
\hline No Item & r hitung & $r$ tabel & Keterangan \\
\hline 1. & 0,687 & 0,1966 & VALID \\
\hline 2. & 0,707 & 0,1966 & VALID \\
\hline 3. & 0,610 & 0,1966 & VALID \\
\hline 4. & 0,618 & 0,1966 & VALID \\
\hline 5. & 0,636 & 0,1966 & VALID \\
\hline 6. & 0,675 & 0,1966 & VALID \\
\hline 7. & 0,209 & 0,1966 & VALID \\
\hline 8. & 0,546 & 0,1966 & VALID
\end{tabular}


Tabel 1, hasilnya $\mathrm{r}$ hitung lebih besar daripada $\mathrm{r}$ tabel jadi dapat diketahui setiap butir pertanyaan dari (1-8) variabel X dapat dinyatakan valid.

Tabel 2. Uji Validitas Variabel Kebutuhan Informasi Publik (Y)

\begin{tabular}{llll}
\hline No Item & r hitung & r tabel & Keterangan \\
\hline 1. & 0,438 & 0,1966 & VALID \\
\hline 2. & 0,529 & 0,1966 & VALID \\
\hline 3. & 0,528 & 0,1966 & VALID \\
\hline 4. & 0,455 & 0,1966 & VALID \\
\hline 5. & 0,676 & 0,1966 & VALID \\
\hline 6. & 0,546 & 0,1966 & VALID \\
\hline 7. & 0,788 & 0,1966 & VALID \\
\hline 8. & 0,659 & 0,1966 & VALID \\
\hline 9. & 0,652 & 0,1966 & VALID \\
\hline 10. & 0,679 & 0,1966 & VALID \\
\hline
\end{tabular}

Tabel 2, hasilnya $\mathrm{r}$ hitung lebih besar daripada $\mathrm{r}$ tabel jadi dapat diketahui setiap butir pertanyaan dari (1-10) variabel Y dapat dinyatakan valid.

Tabel 3. Uji Normalitas

\begin{tabular}{lll}
\hline One-Sample Kolmogorov-Smirnov Test & $\begin{array}{l}\text { Unstandardize } \\
\text { d Residual }\end{array}$ \\
\hline $\mathrm{N}$ & & 100 \\
\hline Normal Parameters ${ }^{\mathrm{a}, \mathrm{b}}$ & Mean &, 0000000 \\
\cline { 2 - 3 } & Std. Deviation & 2,23203714 \\
\hline $\begin{array}{l}\text { Most Extreme } \\
\text { Differences }\end{array}$ & Absolute &, 124 \\
\cline { 2 - 3 } & Positive &, 084 \\
\cline { 2 - 3 } & Negative &,- 124 \\
\hline Test Statistic &, 124 \\
\hline Asymp. Sig. (2-tailed) &, $001^{\mathrm{c}}$ \\
\hline $\begin{array}{l}\text { Exact Sig. (2-tailed) } \\
\text { Point Probability }\end{array}$ &, 085 \\
\hline $\begin{array}{l}\text { a. Test distribution is Normal. } \\
\text { b. Calculated from data. } \\
\text { c. } \text { Lilliefors Significance Correction. }\end{array}$ \\
\hline
\end{tabular}

Tabel 3, mendapatkan hasil probabiltas signifikansi 0,085 dan signifikansi uji normalitas 0,05 maka dapat diketahui jika lebih besar dari signifikansi jadi dapat diketahui bahwa data berdistribusi normal. 
Novita Olivia, Farid Rusdi: Efektivitas Penggunaan Media Sosial @ Kemendagri Terhadap Pemenuhan Kebutuhan Informasi Publik (Survei Pada Pengikut Akun Instagram @ Kemendagri)

Tabel 4. Analisis Korelasi

\begin{tabular}{clrrr}
\hline & & $\begin{array}{c}\text { Efektivitas Penggunaan } \\
\text { media sosial instagram } \\
\text { @ kemendagri }\end{array}$ & $\begin{array}{c}\text { Pemenuhan } \\
\text { Kebutuhan } \\
\text { Informasi Publik }\end{array}$ \\
\hline $\begin{array}{c}\text { Efektivitas Penggunaan } \\
\text { media sosial akun }\end{array}$ & $\begin{array}{l}\text { Person } \\
\text { Correlations }\end{array}$ & 1 & $.736^{* *}$ \\
\cline { 2 - 4 } \begin{tabular}{c} 
instagram @kemendagri \\
\cline { 2 - 4 }
\end{tabular} & $\mathrm{N}$ Sig. (2 tailed) & 100 & .000 \\
\hline $\begin{array}{c}\text { Pemenuhan Kebutuhan } \\
\text { Informasi Publik }\end{array}$ & Person & $.736^{* *}$ & 100 \\
\cline { 2 - 5 } & Correlations & & 1 \\
\cline { 2 - 5 } & $\mathrm{N}$ & 100 & 100 \\
\hline
\end{tabular}

Berdasarkan Tabel 4, menunjukkan hasil analisis korelasi dengan jumlah sampel 100 yaitu nilai koefisien korelasi antara variabel yaitu 0,736. Maka menurut tabel nilai koefisien korelasi 0,60-0,80 maka hubungan antara kedua variabel itu tinggi berarti kuat. Sehingga dapat disimpulkan bahwa hubungan (korelasi) antara Efektivitas penggunaan media sosial akun instagram @kemendagri (Variabel X) terhadap pemenuhaan kebutuhan informasi publik (Variabel Y) adalah cukup positif, yaitu 0,736 .

Tabel 5. Analisis Koefisien Determinasi $\left(\mathrm{R}^{2}\right)$

\begin{tabular}{lllll}
\hline Model & $\mathrm{R}$ & $\mathrm{R}$ Square & $\begin{array}{l}\text { Adjusted } \mathrm{R} \\
\text { Square }\end{array}$ & $\begin{array}{l}\text { Std. Error of } \\
\text { the Estimate }\end{array}$ \\
\hline 1 &, $736^{\mathrm{a}}$ &, 542 &, 537 & 2,243
\end{tabular}

Berdasarkan tabel 5, diketahui kontribusi variabel bebas terhadap variabel terikat disebut dengan $\mathrm{R}$ square ( $\mathrm{r} 2$ ) didapatinya nilai adalah sebesar 0,542 atau 54,2\%. maka disimpulkan akun instagram @kemendagri efektivitas dengan mempunyai kontribusi 54,2\% terhadap pemenuhan kebutuhan informasi publik.

Tabel 6. Uji Hipotesis (T)

\begin{tabular}{|c|c|c|c|c|c|c|}
\hline \multicolumn{2}{|c|}{ Model } & \multicolumn{2}{|c|}{$\begin{array}{c}\text { Unstandardized } \\
\text { Coefficients }\end{array}$} & \multirow{2}{*}{$\begin{array}{c}\text { Standardized } \\
\text { Coefficients } \\
\text { Beta }\end{array}$} & \multirow{2}{*}{$\mathrm{T}$} & \multirow{2}{*}{ Sig. } \\
\hline & & B & Std. Error & & & \\
\hline \multirow{3}{*}{1} & (Constant) & 9,758 & 2,393 & & 4,077 & ,000 \\
\hline & & & & & & \\
\hline & $\begin{array}{l}\text { Penggunaan } \\
\text { media sosial } \\
\text { instagram } \\
@ \text { kemendagri }\end{array}$ & ,899 & ,084 & ,736 & 10,761 & ,000 \\
\hline
\end{tabular}

Untuk menguji efektivitas akun instagram @kemendagri terhadap pemenuhan kebutuhan informasi publik, dapat dilihat nilai t hitung pada tabel diatas sebesar 10,761. Didapati t tabel 1,984. Oleh karena itu t-hitung lebih besar dari t-tabel dengan nilai signifikasi lebih kecil dari 0,05. Maka hipotesi H1 diterima, yaitu adanya 
efektivitas penggunaan media social akun instagram @kemendagri (X) berpengaruh signifikan dalam memenuhi kebutuhan informasi (Y).

Berdasarkan hasil penelitian ini ingin mengetahui seberapa efektif penggunaan media sosial instagram @kemendagri terhadap pemenuhan kebutuhan informasi publik. Efektivitas itu sendiri memiliki pengertian yaitu tercapainya suatu tujuan yang telah ditentukan. Apabila sesuatu tujuan tersebut dicapai sesuai dengan rencana yang telah ditentukan maka hal tersebut efektif. Sasaran dan tujuan yang ingin disampaikan oleh akun instagram @kemendagri adalah isi informasi yang diunggah oleh akun @kemendagri, sehingga hal tersebut bisa dijadikan tolak ukur secara awam oleh masyarakat, jadi apabila akun instagram @kemendagri tersebut memberikan informasi yang terbaru, terpecaya, unggahan yang menarik, dan dapat memenuhi kebutuhan informasi publik. Melalui hasil penelitian yang dilakukan, dan dari hasil jawaban yang didapatkan dari responden melalui kuesioner yang disebar, 35\% dan $61 \%$ dari jumlah responden menjawab setuju dan sangat setuju bahwa unggahan dari akun instagram @kemendagri efektif untuk mendapatkan informasi. Berarti akun instagram @kemendagri terdapat efektivitas dalam pemenuhan kebutuhan informasi publik karena menggunakan bahasa yang mudah dipahami. Hasil dari penelitian ini juga berhubungan dengan teori Uses and Gratification (Teori Kepuasaan dan Penggunaan) dimana teori ini menjelaskan bahwa setiap individu (masyarakat/publik) dapat memilih media berbagai media untuk pemenuhan kebutuhannya. Berdasarkan teori tersebut dapat disimpulkan bahwa instagram @kemendagri dipilih oleh followers karena media ini mengemas pesan atau informasi yang efektif dan dapat dipercaya untuk khalayak dan bisa memenuhi kebutuhan informasinya secara rutin.

\section{Simpulan}

Berdasarkan pembahasan diatas dan juga yang dijelaskan pada bab-bab sebelumnya, peneliti menarik kesimpulan: (1) Dalam penelitian ini, hasil uji statistik dengan rumus korelasi person Product Moment diperoleh bahwa tingkat korelasi Efektivitas akun instagram @kemendagri terhadap pemenuhan kebutuhan informasi publik memiliki hubungan yang kuat. (2) Berdasarkan hasil penelitian, teori kepuasan dan penggunaan telah diuji dan terbukti bahwa akun instagram @kemendagri ini dipilih oleh masyarakat yaitu pengikut akun instagram @kemendagri sebagai media untuk memenuhi informasinya. (3) Adanya hasil uji koefisien determinasi dengan didapatinya nilai $54,2 \%$ jadi dapat diketahui bahwa penggunan akun instagram @ kemendagri efektivitas berpengaruh terhadap pemenuhan kebutuhan informasi publik (Y) dengan memberikan kontribusi adalah sebesar 54,2\%.

\section{Ucapan Terima Kasih}

Terima kasih saya kepada Dosen pembimbing dan seluruh dosen fakultas ilmu komunikasi yang memberikan arahan untuk menyelesaikan penelitian ini, orang tua saya yang memberikan doa serta dukungan terhadap saya, dan teman-teman saya Syifa, Ece, Audri, dan juga Chelsea sebagai teman yang berada dalam posisi memperjuangkan skripsi, serta kepada responden yang bersedia untuk mengisi kuosioner ini. Saya berharap jurnal ini bisa memberikan refrensi bagi orang lain. 
Novita Olivia, Farid Rusdi: Efektivitas Penggunaan Media Sosial @ Kemendagri Terhadap Pemenuhan Kebutuhan Informasi Publik (Survei Pada Pengikut Akun Instagram @ Kemendagri)

\section{Daftar Pustaka}

Ardianto

E.

(2011).

Komunikasi

massa.

https://www.google.co.id/books/edition/Komunikasi_massa/euYPzgEACAAJ ?hl=en

Helen, H., \& Rusdi, F. (2019). Pengaruh Penggunaan Media Sosial Akun Instagram @Jktinfo Terhadap Pemenuhan Kebutuhan Informasi Followers. Prologia, 2(2), 355-362. https://journal.untar.ac.id/index.php/prologia/article/view/3712

Maunley, Y. (2016). Pengertian Efektivitas - EFEKTIVITAS. https://teoriefektivitas.blogspot.com/2016/02/pengertian-efektivitas.html

Perdana, C. R. G., Rizal, E., \& Khadijah, U. L. S. (2012). Hubungan Twitter Jatinangorku dengan Pemenuhan Kebutuhan Informasi Seputar Daerah Jatinangor bagi Followers. Students E-Journal, I(1), 19. http://jurnal.unpad.ac.id/ejournal/article/view/1247

Solis, B. (2011). The Complete Guide for B R A N D S and and Measure Success in the New Web BRIAN SOLIS Foreword by.

Sugiyono. (2016). metode penelitian kuantitatif, kualitatif. In Alfabeta, $c v$.

Susanti, D. (2019). ANALISIS REGRESI DAN KORELASI - Google Books. https://www.google.co.id/books/edition/ANALISIS_REGRESI_DAN_KORE LASI/98XODwAAQBAJ?hl=id\&gbpv=1\&dq=analisis+regresi+dan+korelasi $\&$ printsec $=$ frontcover

Wahyuni, S. (2020). KINERJA SHARIA CONFORMITY AND PROFITABILITY INDEX DAN FAKTOR DETERMINAN - Google Books. https://www.google.co.id/books/edition/KINERJA_SHARIA_CONFORMIT Y_AND_PROFITABIL/wHUJEAAAQBAJ?hl=en\&gbpv=1\&dq=Kinerja+S haria+Conformity+And+Profitability+Index+Dan+Faktor+Determinan.\&prin tsec $=$ frontcover

Widhiarso, W. (2012). Tanya Jawab tentang Uji Normalitas. 1-5. http://widhiarso.staff.ugm.ac.id/files/Tanya Jawab tentang Uji Normalitas.pdf

Widiyanto, M. A. (2013). Statistika Terapan: Konsep \& Aplikasi SPPS dalam Penelitian Bidang Pendidikan, Psikologi \& Ilmu Sosial Lainnya. PT Elex Media Komputindo. 